\title{
Article \\ Numerical Evaluation for Roads Considering the Addition of Geogrids in Karst Geohazards Zones
}

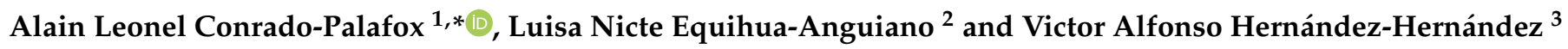 \\ 1 Civil \& Environmental Engineering, The University of Western Ontario, London, ON N6A 5B9, Canada \\ 2 GEIC-CFE Federal Electricity Commission, San Juan, Mexico City 03730, Mexico; luisa.equihua@cfe.mx \\ 3 Graduate Program in Biosciences, Life Science Division, University of Guanajuato, Irapuato 38116, Mexico; \\ va.hernandezhernandez@ugto.mx \\ * Correspondence: aconrado@uwo.ca; Tel.: +52-9992-17-28-90
}

check for

updates

Citation: Conrado-Palafox, A.L.;

Equihua-Anguiano, L.N.;

Hernández-Hernández, V.A.

Numerical Evaluation for Roads

Considering the Addition of

Geogrids in Karst Geohazards Zones.

Infrastructures 2021, 6, 120. https:/ /

doi.org/10.3390/infrastructures6090120

Academic Editors: Fabrizio D'Amico,

Luca Bianchini Ciampoli and

Fabio Tosti

Received: 31 July 2021

Accepted: 26 August 2021

Published: 30 August 2021

Publisher's Note: MDPI stays neutral with regard to jurisdictional claims in published maps and institutional affiliations.

Copyright: (c) 2021 by the authors. Licensee MDPI, Basel, Switzerland. This article is an open access article distributed under the terms and conditions of the Creative Commons Attribution (CC BY) license (https:/ / creativecommons.org/licenses/by/ $4.0 /)$.

\begin{abstract}
Design of road infrastructure in karst terrain is a challenge for any geotechnical condition caused by the weathering of the subsoil. Previous investigations pointed out the efficiency of the roads with geogrids, however there are few studies analyzing road reinforced under karst geohazards. This paper presents a numerical study of the geogrid additions in a typical Mexican road and considering 19 cavities in the subsoil due to failures of the roads in these terrains. The rocks and the soil were simulated by Hoek-Brown and Mohr-Coulomb constitutive models, considering specific characteristics of karstic materials. Hence, it was carried out in different two-dimension finite element models to analyze the geogrid behavior and its benefits. First, the geogrid position was varied inside of the road structure and applying a heavy truck load in its surface and finally, underground cavities were sequentially opened in the numerical model. It was established the best combination of the road-geogrid structure construction and the influence when cavities are developed underground analyzing the stress paths in the medium. From this study, it is found, that when the geogrid layer is embedded between bedrock and subgrade, the failure is mitigated, observing an increase in the factor of safety even with 19 voids presence in the model. Concluding that the geogrid is an adequate solution of reinforcement of roads.
\end{abstract}

Keywords: numerical simulation; karst terrain; cavities; roads \& highway; geogrid; shear stress factor

\section{Introduction}

Karst geomorphology in the world is produced by dissolution of carbonate rocks, developing surface characteristics as poljes, sinkholes (dolines), shallow holes and it is through these voids or conduits that groundwater can flow [1]. The karst landscape is part of the $20 \%$ of the area in the earth [2] and according to Conrado-Palafox [3], the karst activity has a high influence on the stresses in the ground that produces settlements on the terrain. The settlement represents a handicap in the road design and in its structural performance as well as in other constructions.

In the specific case of Yucatan, Mexico, the karst phenomena have been investigated several occasions and it was pointed out that its formation is very complex and where several non-traditional factors intervene [4,5]. Furthermore, Springall [6] explained that the biggest dissolution area is located in the first meters of subsoil and Bauer-Gottwein [7] mentions that there are several caves with $2.0 \mathrm{~m}$ diameter less than $15 \mathrm{~m}$ deep (Figure 1).

Determining the specific location of the cavities in Yucatan is not easy, because the dolines density is variable, and they are located in random points in the entire Yucatan region [8]. Therefore, there are several studies about the mapping karst system [9-12] that can be used in construction, nevertheless, Bonacci [13] established that industrial development in particular regions, such as water pumping causes redistribution in karst catchments, which strongly and dangerously affects processes of water circulation and weathering. The city of Merida, Yucatan, concentrates $50 \%$ of the population in $2 \%$ of the State area and 
most of the industries are also located on the outskirts of the capital, the demographic and economic growth in Yucatan peninsula in recent years have caused changes in the hydrological response and flow of water cycle, due to the increase in water consumption but with a $23 \%$ decrease in groundwater recharge [14]. It is important to describe the water balance because, although the solubility of limestone in pure water is extremely low [15], the $\mathrm{CO}_{2}$ emissions from human activities such as urbanization, stone clearing, quarrying, and deforestation accelerate the weathering in the karst landscape [16,17].

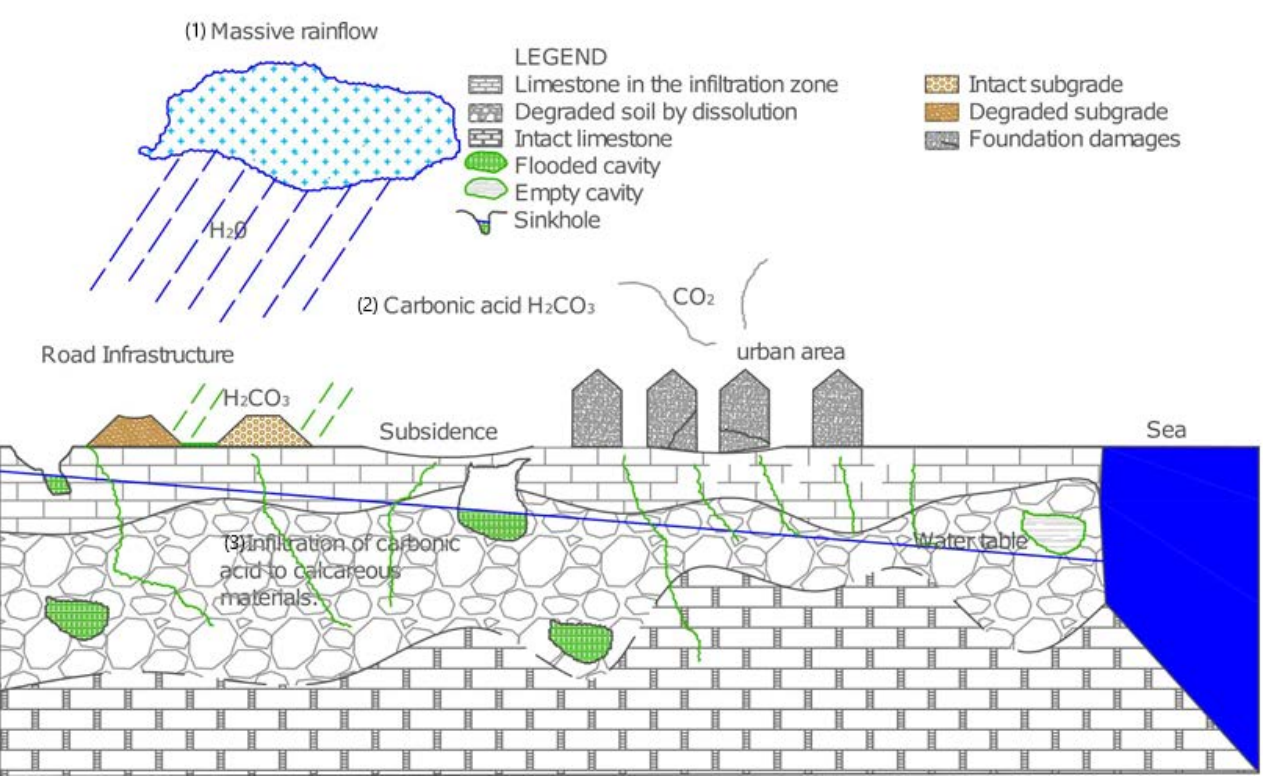

Figure 1. Scheme of the Yucatan karst landscape.

The high frequency of mechanical failure in karst terrains is primarily due to the low strength of the young limestone. Therefore, collapse is an inevitable consequence of the excessive tensile stresses as result of the geo-material dissolution [18]. The mechanical failures have been treated by applying several methods, such as concrete injection through the boreholes [19], however, this can cause differential settlements related to the isolated impermeable material and contribute to the change of the local hydrogeological condition [20].

The typical road structure constructed in Yucatan is shown in Figure 2. The road thickness is thin because of the Yucatecan flat rock platform, and although the section has had good performance over the limestone platform, the road suffers a differential displacement on account of the presence of a cavity as is found by Gutiérrez [21] and Saenseela [22]. Figure 3a shows an example of the soil surface in Merida, Mexico, and Figure $3 b, c$ show a cavity next to a road. In those it is possible to observe one effect of the karst activity and although the effect and the problematic is evident, Yucatan road Standard does not consider an alternative to avoid the karst effect.

\section{Layers of a typical road structure in Yucatán, México}

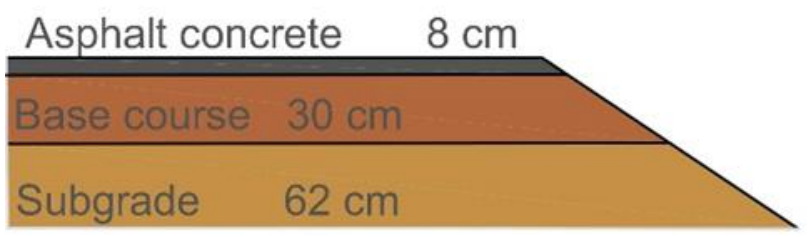

Figure 2. Schemes of layers and thickness of a typical road structure in Yucatán [23]. 


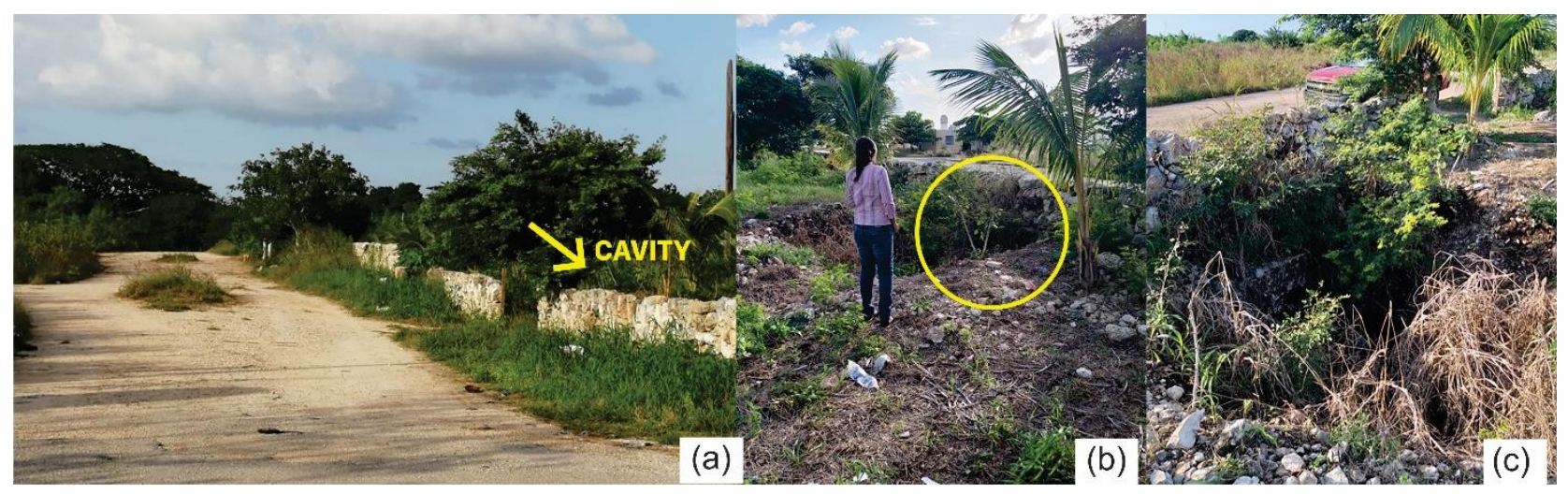

Figure 3. Cavity near roads without special road design in Caucel city, Merida, Yucatan; Mexico. (a) Road next to the cavity, $(\mathbf{b}, \mathbf{c})$ Photography of the cavity and.

In this way, this study is focused in proposing a solution for the road problems caused by the karsticity phenomena, considering a typical road structure as established in the Mexican Normative [23] and considering the geogrid inclusions in design, through the improvement observed and according to the numerical results presented in this work.

\section{Background of Reinforcements with Geogrids}

Geogrids are an economic solution for road problems in soils with poor bearing capacity [24-27] or for reducing the rutting damage in base course and subgrade layers [28]. In the way to find solutions, several numerical methods have been developed to analyze geogrids improvement and some of these conclude that the use of one geogrid layer or two of them increase the bearing capacity of the soil, because of the well distributed stresses along of the geogrids [29]. Railway design is another infrastructure that uses the numerical methods to analyze the use of geogrids, such as Jiang [30] that established the ballast/subballast interface as the optimum geogrid placement location and the improvement is more notorious when there is a poor subgrade than a rigid one. Similarly, Ngo [31], concluded that the use of geogrid reduces ballast dilatation carrying out discrete element method and physical laboratory test.

Recent studies have explored the mitigation of a road structure over only one void such as Wang [32], who carried out a finite element modelling of an embankment over a large sinkhole and concluded that the geosynthetic has a more significant influence on the settlement at the base of the embankment than in the crest, it should be noted that this investigation also add drilled shafts as a road improvement and the layer under the embankment was a silty clay. Moreover, Sireesh [33] concluded with laboratory scale model tests that a geocell reinforced sand over clay bed with a circular void is an excellent reinforcement to increase the bearing capacity and reduce settlement of the clay subgrade. Finally, Galve [34] points out the profitable use of geosynthetics in road structures to mitigate the extra cost due to cavity damages, based on probabilistic methodology and sinkholes area data and cos-benefit analysis.

Under these statements, an option to improve the strength and mechanical properties of soil is to introduce a geogrid as a reinforcement surface element. However, there are few investigations about the improvement of the geogrids in karst terrains or investigations of preventing road settlement problems when the subsoil has a subsidence problem due to the weathering effect of the material, furthermore, most studies in the field have only focused on clay sublayers and with only one cavity in the model. This study provides new insight into road reinforcement with geogrids but considering several voids in the terrain and pointing out the best position of a geogrid layer in the road structure in order to mitigate road failures due to the subsidence in the terrain caused by many cavities. 


\section{Material and Methods}

The objective of the numerical analyses in PLAXIS ${ }^{\circledR}[35]$ is to determine the better position and the combination of the geogrids placed under different layers of the road structure studied (see Figure 2). Obtained results were analyzed in function of the capacity of mitigation of the soil failure and the effect of the presence of several cavities in the ground, being this part the main handicap in the analyzed zone, because as described in [36] the Yucatan karst landscape is characterized for having several small holes in the subsoil, as can be seen in Figure 5.

The numerical modelling was based on the conceptual flow chart showed in Figure 4. Firstly, the input parameters were stablished such as the size of the model with the length of each layer (granular soil and rock layer), the boundary conditions and the geometry and positions of each of the 19 cavities. Secondly, the road structure was added in the model placing a geogrid layer between each layer, at the end one of the cases analyzed in this study had 4 geogrids layer and other cases had only 1 geogrid in the bottom and/or in the crest of the road. Once the road reinforcement structure was completed, the static truck load was applied over the asphalt layer. The methodology of opening and creating the cavities in the finite element model was obtained from Conrado-Palafox [3]. In the following section each step of the flow chart is explained more in detail.

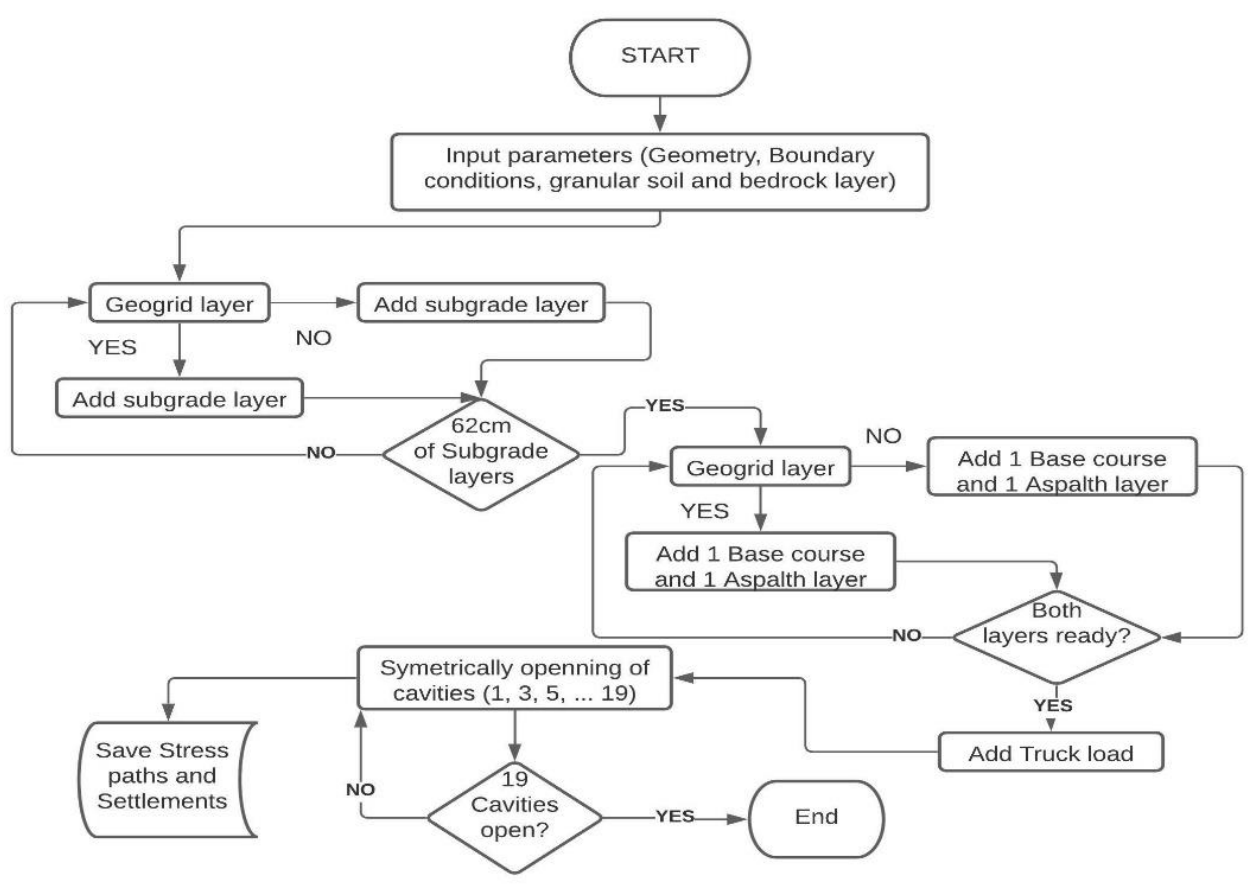

Figure 4. Flow chart of the numerical modelling of a road reinforcement with geogrids in a karst terrain.

\subsection{Numerical Modelling}

The geometry of the plane strain (2D) model is $200 \mathrm{~m} \times 50 \mathrm{~m}$ to avoid numerical errors and the boundary considerations are: the bottom is defined by the restriction of movements on the x-axis (horizontal) and y-axis (vertical), whereas on the vertical sides only $x$-axis was restricted as is showed in Figure 5. Over the terrain, the road structure with $11 \mathrm{~m}$ base and $8 \mathrm{~m}$ roadway was laid. Figure 6 illustrates the numerical model soil layers, the geogrid position $N_{1}, N_{2}, N_{3}$ and $N_{4}$, the truck load and the nomenclature used. 


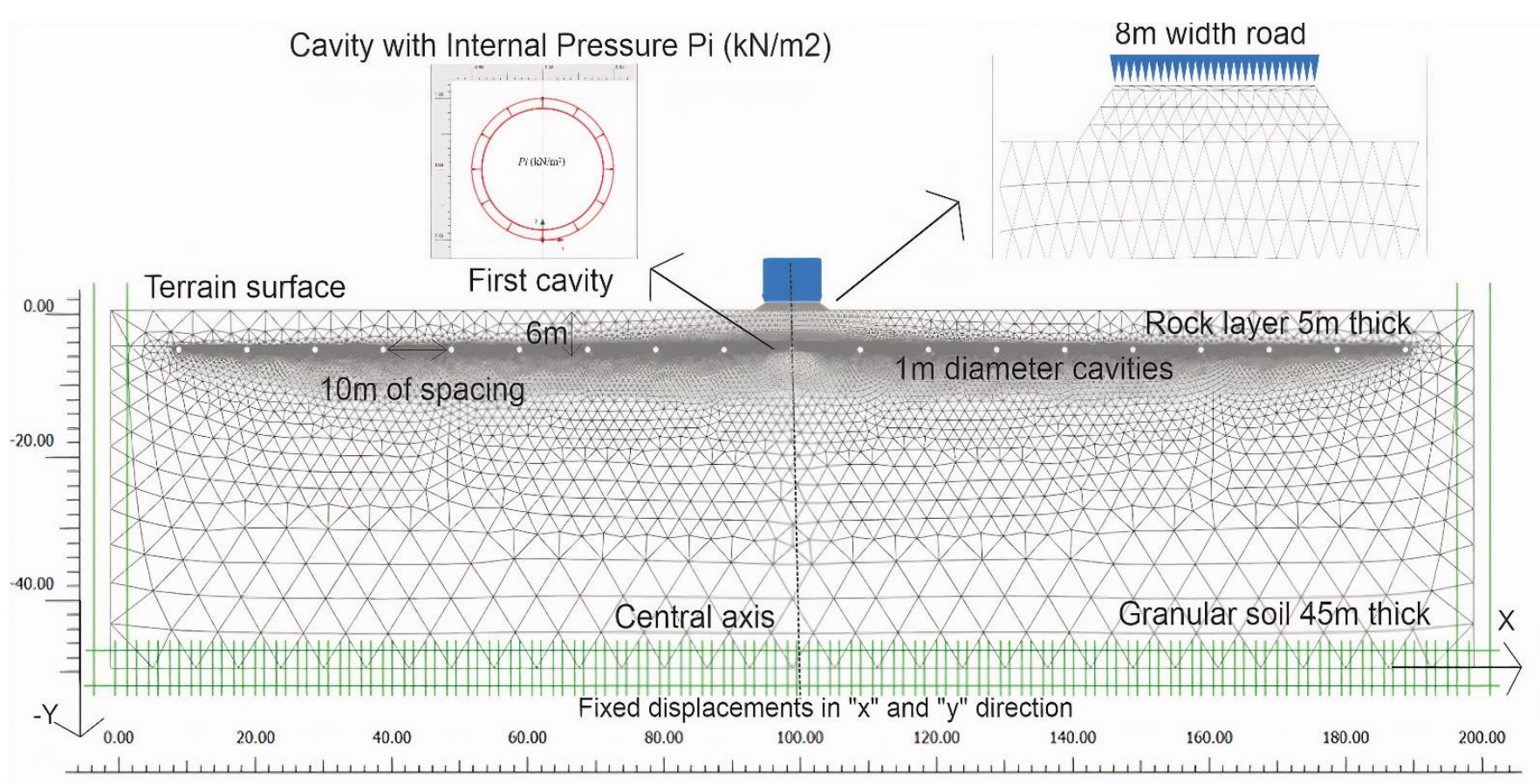

Figure 5. The numerical model with the mesh discretization using 32,779 triangle elements and 65,940 nodes.

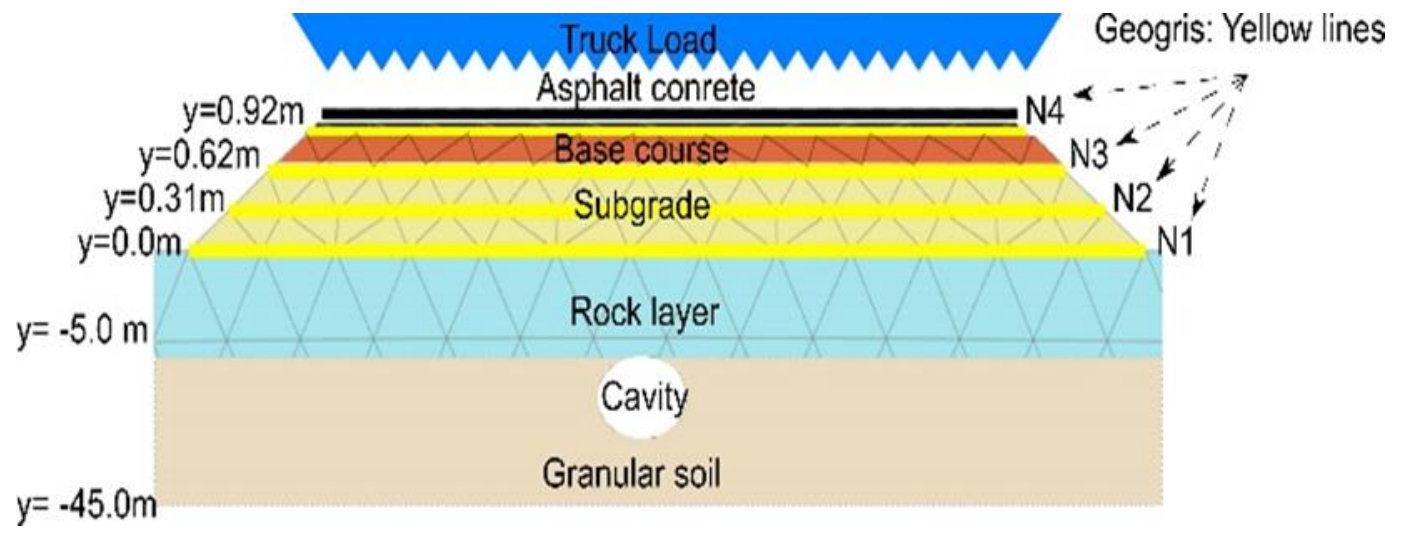

Figure 6. Karst terrain with the road structure and the location of the four geogrids $-N_{1}, N_{2}, N_{3}$ and $N_{4}$.

The numerical modelisation was generalized in four principal "Phases" as is exemplified in Table 1. In the "Initial phase", the stratigraphy composed by a rock layer and granular soil was modeled and then, the road structure considering its own weight (Road structure phase) was created to in the third Phase (Phase of the Static load) apply the heavy truck load $\left(4.84 \mathrm{kN} / \mathrm{m}^{2}\right)$ [37].

The last Phase named "Cavities" was developed in 10 different steps to simulate the karst evolution and the cavities were placed under the rock layer in the model as is schematized in Figure 5. The first step of this Phase start with one 1-m diameter cavity at the mid of the numerical model (see Figure 6) and in the next 9 steps, it was added two cavities in each one, until the 18 cavities were symmetrically created. Although the road seems to be influenced only by three cavities it was important to study the effect of the other cavities, to evaluate the effect of the terrain surface subsidence. 
Table 1. Phases in the numerical modelisation.

\begin{tabular}{cc}
\hline Phases & Condition \\
\hline Initial & Stratigraphy (rock layer and granular soil) \\
Road structure & $\begin{array}{c}\text { Different road layers and the geogrids combinations as } \\
\text { described in Table } 2\end{array}$ \\
Static load & Truck load in the road surface $\left(4.84 \mathrm{kN} / \mathrm{m}^{2}\right)$ \\
1 Cavity in the granular soil on central axis & 3 Cavities in the granular soil \\
& 5 Cavities in the granular soil \\
7 Cavities in the granular soil \\
9 Cavities in the granular soil \\
11 Cavities in the granular soil \\
13 Cavities in the granular soil \\
15 Cavities in the granular soil \\
17 Cavities in the granular soil \\
19 Cavities in the granular soil
\end{tabular}

Table 2. Description of the geogrid locations, thickness of the layers of the road structure and the cases analyzed taking into account the $R_{\text {inter\# }}=1.0,0.8$ and 0.67 , in the numerical modeling.

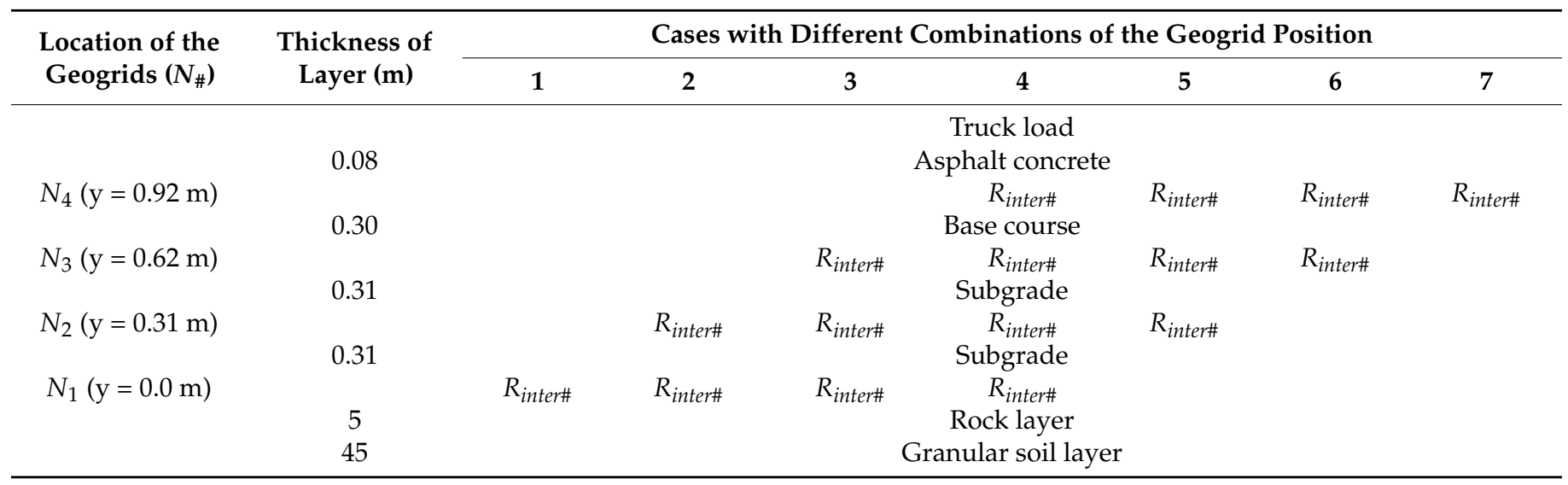

Furthermore, the cavities modelisation, follow the criterion proposed by ConradoPalafox [3], since it demonstrated the numerical stability of the cavities with a FEM modeling and the change of the stresses developed in the rock layer. The cavities are subject to an internal pressure to avoid collapse (See Figure 5) [38] in the phases denominated Cavities (Table 1), and thus this pressure (Pi) leads a simplified model of the cavities before the collapse, therefore internal pressure values were obtained iteratively in the model, until to find a minimal internal pressure.

For the case of the Road Structure Phase, it was modeled in four steps in order to add geogrids between the four road layers corresponding to the subgrade (divided in two thicknesses); the base course and the asphalt concrete layer as can be seen in Figure 6 .

Table 2 enlists the seven "Cases" that were modeled with the geogrid variations in its position on the pavement structure. All cases were analyzed varying three different interface values $\left(R_{\text {inter\#}}\right)$ between the borders of the geogrid and the different pavement layers, according to those reported in the bibliography. The selected values of interface $\left(R_{\text {inter\#) }}\right.$ were $R_{\text {inter } 1}=1$ (Rigid), $R_{\text {inter } 2}=0.8$ [30] and $R_{\text {inter } 3}=0.67$ [39]. This values where all considered to study its influence in the numerical results, because this interaction represented by $R_{\text {inter\# }}$ between the geo material and the geogrids, depends on several conditions, such as compaction layer, geogrid material, geogrid aperture size among other things, then it is difficult to select the correct value without an in-situ test.

In Table 2, the first line indicates that the "Truck load" is modeled in the seven cases and the sequence of the next lines in this same Table 2, follows the arrangement of the 
model, starting at the top of this with the asphalt concrete layer and ending at the rock layer and the granular soil. The thickness layers are indicated in this Table.

The columns colored in the "Cases", show the considerations taken in each specific case. Case 1 considers one geogrid $\left(N_{1}\right)$ set between the rock layer and the subgrade interface ( $\mathrm{y}=0.0 \mathrm{~m}$, terrain surface) and the Rinter\# value was varied as is specified above. Case 2 considers two geogrids layers, one at the rock/subgrade interface $\left(N_{1}, y=0.0 \mathrm{~m}\right)$ and the other embedded inside of the subgrade $\left(N_{2}, \mathrm{y}=0.31 \mathrm{~m}\right)$ and the $R_{\text {inter }}$ interface values were varied as in the Case 1 . This sequence is followed until the Case 4 in which, four geogrids were placed as is represented in Figure 6. Then, from the Case 5 until the Case 7 one geogrid was removed consecutively, till the pavement structure remains with a geogrid $\left(N_{4}, y=0.92 \mathrm{~m}\right)$ placed among the asphalt concrete layer and the base course.

\subsection{Geotechnical and Geogrids Parameters}

Geotechnical properties considered correspond to the stratigraphy near the coast of Yucatan [40] and were taken from [3]. The material parameters and the constitutive models for the road structure and the geogrids are listed in Table 3. From the simple compression bedrock $\sigma c i=34.9 \mathrm{kN} / \mathrm{m}^{2}$, the material constant $m i=8$ and the geological strength index $G S I=30$ obtained of the in-situ material, the effective friction angle $\left(\phi^{\prime}=24.30^{\circ}\right)$ and the effective cohesion $\left(c^{\prime}=1.3 \mathrm{kN} / \mathrm{m}^{2}\right)$ were calculated through the RocData 5.0 software [41]. For the case of the geogrids, the normal stiffness is taking according to PLAXIS ${ }^{\circledR}$ [35].

Table 3. Geotechnical parameters used in FEM for the different layers.

\begin{tabular}{ccccccc}
\hline Layer & $\begin{array}{c}\text { Constitutive } \\
\text { Model }\end{array}$ & $\begin{array}{c}\boldsymbol{\gamma} \mathbf{k} / \mathbf{m}^{\mathbf{3}} \\
\mathbf{k N} / \mathbf{m}^{\mathbf{2}}\end{array}$ & $\begin{array}{c}\mathbf{E A} \\
\mathbf{k N} / \mathbf{m}\end{array}$ & $\begin{array}{c}\boldsymbol{\phi}^{\prime} \\
{ }^{\prime}\end{array}$ & $\boldsymbol{v}$ \\
\hline Granular soil & Mohr-Coulomb & 10.1 & 20,000 & - & 26 & 0.33 \\
Bedrock & Hoek-Brown & 12.2 & $2,550,000$ & - & 24.3 & 0.25 \\
Subgrade & Mohr-Coulomb & 15 & 170,000 & - & 34 & 0.40 \\
Base course & Mohr-Coulomb & 17 & 345,000 & - & 40 & 0.35 \\
Asphalt & Linear Elastic & 23 & $2,000,000$ & - & - & 0.25 \\
concrete & Normal Stiffness & - & - & 250 & - & - \\
Geogrid & & & & & & - \\
\hline
\end{tabular}

\subsection{Shear Stress Factor (FSS) and Stress Paths $\left(\tau_{m o b}-p^{\prime}\right)$}

Results were analyzed in function of the Shear Stress Factor named FSS in this work and obtained according to the Equation (1).

$$
F S S=\tau_{\max } / \tau_{m o b}
$$

where, FSS is the Shear Stress Factor, $\tau_{\max }$ is the maximum shear stress that the material can reach (failure envelope) according to its mechanical resistance parameters and $\tau_{m o b}$ is the acting shear stress mobilized due to loads or cavities.

The stress paths were obtained by Equations (2) and (3) [42].

$$
\begin{gathered}
p^{\prime}=\left(\sigma_{1}^{\prime}+\sigma_{3}^{\prime}\right) / 2 \\
\tau_{m o b}=\left(\sigma_{1}^{\prime}-\sigma_{3}^{\prime}\right) / 2
\end{gathered}
$$

where, $p^{\prime}$ is the mean effective stress $\left(\mathrm{kN} / \mathrm{m}^{2}\right) ; \tau_{m o b}$ is the mobilized shear strength $\left(\mathrm{kN} / \mathrm{m}^{2}\right)$; $\sigma_{1}^{\prime}$ is the major effective principal stress $\left(\mathrm{kN} / \mathrm{m}^{2}\right)$ and $\sigma_{3}^{\prime}$ is the minor effective principal stress $\left(\mathrm{kN} / \mathrm{m}^{2}\right)$.

\section{Results}

\subsection{Analysis of the Shear Stress Factor (FSS) Due to the Cavities Generation and the Rinter\# Variation}

Figure 7 shows the FSS along of two road layers at $\mathrm{y}=0.0 \mathrm{~m}$ and $\mathrm{y}=0.92 \mathrm{~m}$ in the road structure, considering only the truck load and the cavities without geogrids. Results 
as taken as a point of reference to have comparisons when the geogrids are added in the structure. In this analysis, the $R_{\text {inter\# }}$ value between the road layers was $R_{\text {inter } 1}=1$. Good performance was observed in the structure with static load and 0 cavities, producing values greater than 2 of the Shear Stress Factor (FSS) in the base of the structure ( 0 cavities, $y=0.0 \mathrm{~m}$ ) and around of 2 in the top of the base course ( 0 cavities, $y=0.92 \mathrm{~m})$. In the top of the structure road $(\mathrm{y}=0.92 \mathrm{~m})$ with 0 cavities, the FSS is lower than in the base course layer, because it absorbs more of the static truck load stress and a lesser FSS is developed in this layer.

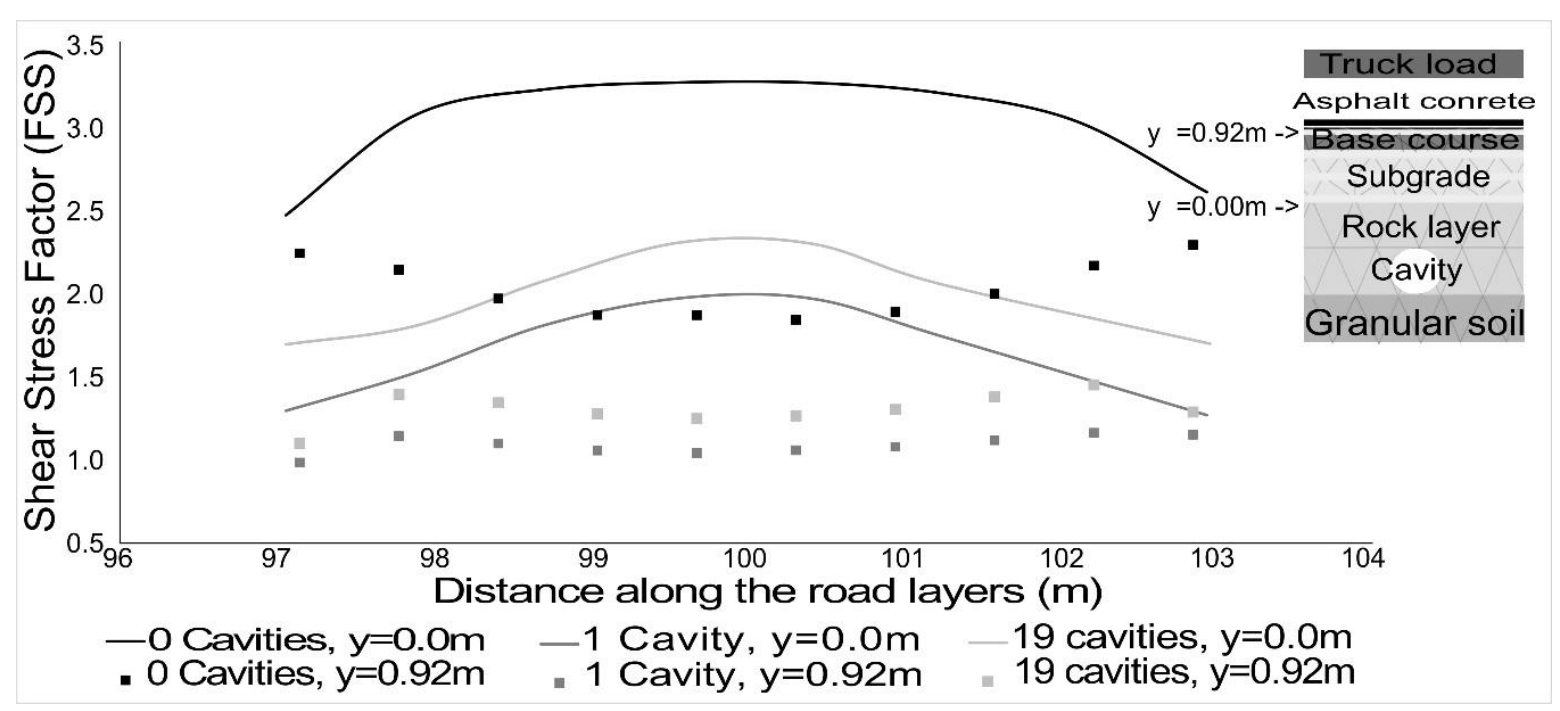

Figure 7. Mobilized FSS along of the road layers $\mathrm{y}=0.0 \mathrm{~m}$ and $\mathrm{y}=0.92 \mathrm{~m}$ considering the truck load acting in the surface without geogrids in the road structure and 0,1 and 19 cavities.

This same Figure shows the performance of the road layers with the truck load and 1 and 19 cavities are simulated in the model. When there is 1 cavity in the central axis, the FSS decreased in both levels, at the top of the base course layer ( 1 cavity, $\mathrm{y}=0.92 \mathrm{~m}$ ) and in the base of the structure ( 1 cavity, $y=0.0 \mathrm{~m}$ ). After that, the FSS has a slight increase in the road structure, pointing out that the FSS value depends on the separation of the cavities with the road structure; furthermore, the failure of the cavities has reached its maximum deformation and the FSS is practically 1. Relying on Figure 7, the need to reinforce the structure due to the reduction in the FSS for cause of the cavities in the ground.

Influence of the three interface values $R_{\text {inter } 1}=1, R_{\text {inter } 2}=0.8$ and $R_{\text {inter } 3}=0.67$ are illustrated in Figure 8 at $y=0.62 \mathrm{~m}$, along of the top of the subgrade layer. Results for Case 1 (only one geogrid in the $N_{1}$ position) and Case 4 (four geogrids located in $N_{1}, N_{2}, N_{3}, N_{4}$ depths) show the influence of the 1 cavity and 5 cavities in the bedrock. The influence is in the reduction of the FSS values when the interface value $R_{\text {inter\# }}$ is decreased, which points out that Case 1, 1 Cavity, $R_{\text {inter } 3}=0.67$ and Case 4,5 Cavities, $R_{\text {inter } 3}=0.67$ generates less FSS in the top of the subgrade layer $(\mathrm{y}=0.62 \mathrm{~m})$ than the other interface values of $R_{\text {inter } 1}=1.0$ and $R_{\text {inter } 2}=0.80$. In the same way, it is possible to observe that when more cavities are developed the FSS is increased, due to the failure of the cavities and in some way the stabilization of the surface terrain.

From this graph and for the next presented results, the interface $R_{\text {inter } 3}=0.67$ that caused the most unfavorable Shear Stress Factor (FSS) was selected. Furthermore, when only a geogrid is considered in the road structure, the FSS can change markedly in the road centre. 


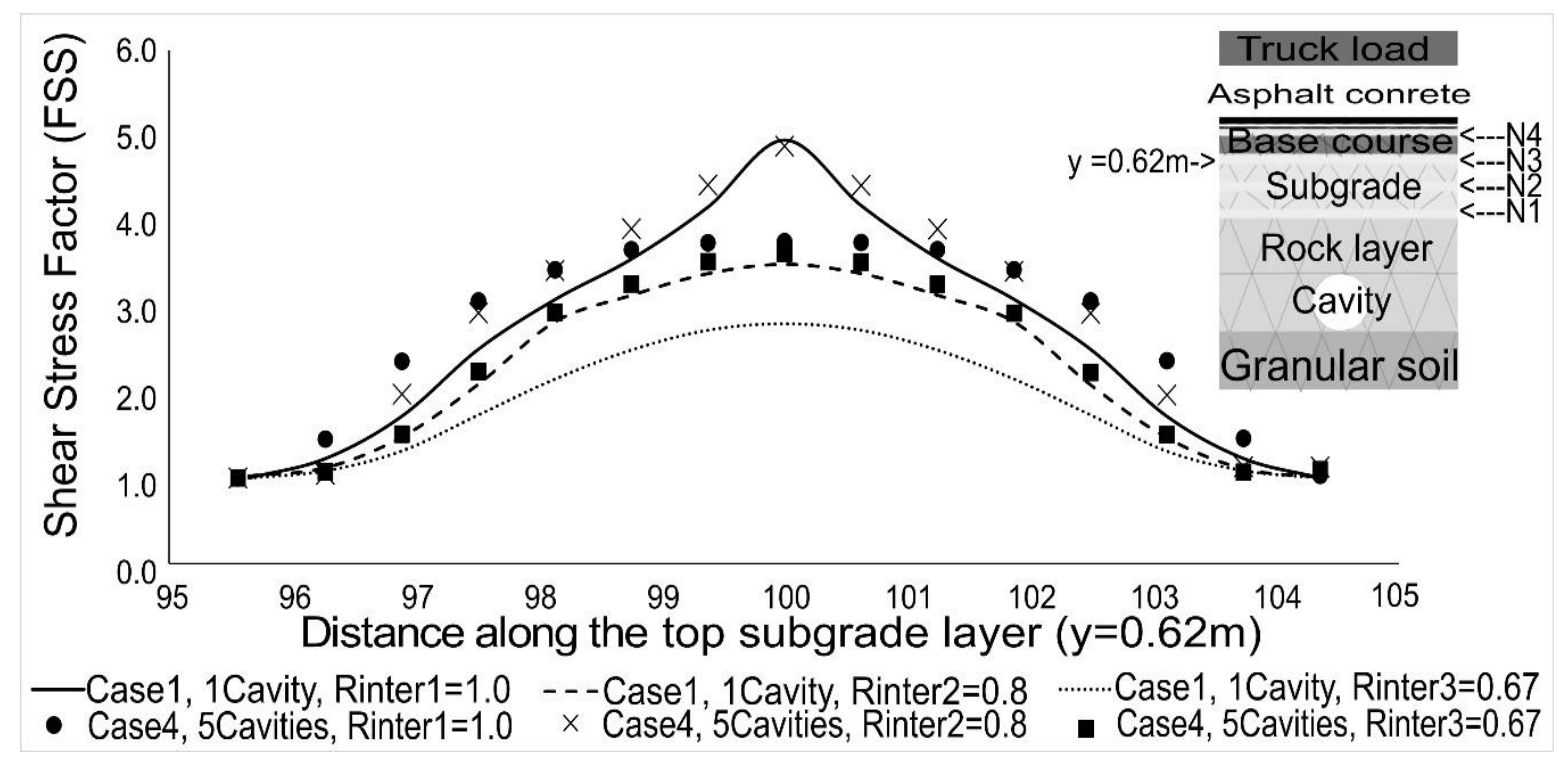

Figure 8. Mobilized FSS along of the top subgrade layer at $\mathrm{y}=0.62 \mathrm{~m}$ for the Cases 1 and 4 ( 1 and 5 cavities respectively), considering three different interface values Rinter\# and varying the number of the cavities in the geotechnical medium.

\subsection{Mobilized FSS in the Different Road Layers for the Seven Analysed Cases}

In Figure 9 the impact in the FSS is appreciated in the top of the subgrade layer $(y=0.62 \mathrm{~m})$ for all the Cases and for a $R_{\text {inter } 3}=0.67$, considering the truck load and 0,1 , 3 and 19 cavities. For Figure 9a) with 0 cavities and the truck load, the Cases 1, 3 and 5 (black line, grey line and dashed line respectively), enhance the road structure increasing the FSS compared to the Case without geogrids (black circle marks). When there is 1 cavity (Figure $9 \mathrm{~b}$ ), the FSS decrease in the top of the subgrade layer compared to the graph with 0 cavities and the Case 4 (cross mark with $N_{1}, N_{2}, N_{3}$ and $N_{4}$ geogrids) is the best combination to improve the structure reaching a maximum $F S S=4.8$ in the center of the road. Cases 1, 3 and 5 are slightly lower in its FSS values. When there are 3 and 19 cavities in the model (Figure 9c,d), Case 4 also has the higher FSS, followed by the Cases 1, 3 and 5 . In this Figure, the increase in the FSS is associated to the soil stresses arrangement from the 3 cavities to the 19 cavities in the model, corroborating the results obtained in Figure 8 but, for the seven cases using the improvement of the road structure with geogrids. Evidently there are some cases that the increment in the FSS value is enhanced such as the Cases 1 and 3. On the other hand, Case 6 (geogrids in $N_{3}$ and $N_{4}$ ) and Case 7 (geogrid in $N_{4}$ ) indicate with the triangle marks and the dotted line respectively, show no improvement in the subgrade layer, concluding that the reinforcement in the base course layer is negligible for the subgrade.

The performance in the base course layer $(y=0.92 \mathrm{~m})$ is presented in Figure 10 with the same considerations as the previous Figure. In Figure 10a) with only the truck load and 0 cavities, the Cases 1 and 6 have higher FSS than the Case without geogrids and when there is 1 cavity (Figure 10b) the behavior is divided in two groups, one with FSS more than 2 and the other lesser than it. Cases 2, 3, 4 and 5 present the higher values and this behavior is the same when there are 3 cavities in the model. On the other hand, when there are 19 cavities (Figure 10d) the behavior is similar with the particularity that the Cases 1 and 6 increment their FSS values. For the top of the base course layer $(\mathrm{y}=0.92 \mathrm{~m})$, only Case 7 (one geogrid $N_{4}, \mathrm{y}=0.92 \mathrm{~m}$ ) does not show an improvement in the FSS. 


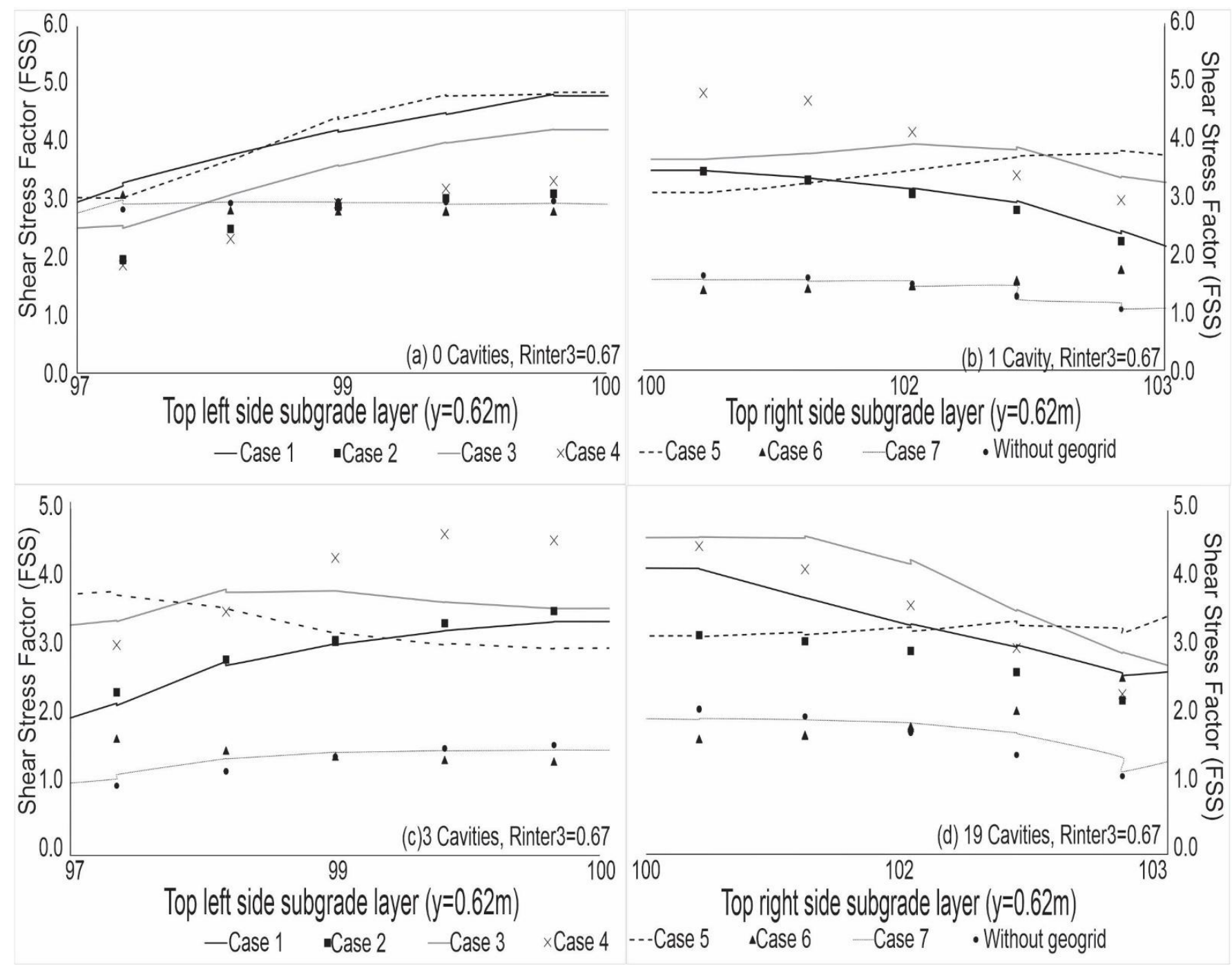

Figure 9. Graph groups of Mobilized FSS along of the subgrade layer $\mathrm{y}=0.62 \mathrm{~m}$, considering the seven Cases, $R_{\text {inter } 3}=0.67$, truck load and (a) 0 cavities, (b) 1 cavities, (c) 3 cavities and (d) 19 cavities in the soil.

According to the Figures 9 and 10, Case 3 and Case 5 (grey lines and dashed lines respectively) are the best combinations to increment the FSS in both, the subgrade and the base course layers. Case 2 is also an adequate combination since its FSS value does not vary a lot with the different numbers of the cavities, and despite that in the subgrade layer it does not have a higher FSS, this combination improves the base course layer. Highlighting that in order to generate higher FSS in the road layer, the best option is to enhance the middle and the top of the subgrade layer. Case 4 (cross marks) does not represent an adequate option due to the excess of geogrid additions which results in the cost of the road.

\subsection{Stress Paths $\left(\tau_{m o b}-p^{\prime}\right)$ and Kinematics in the Different Road Layers Using Geogrid Additions}

Figure 11 illustrates the stress paths $\left(\tau_{m o b}-p^{\prime}\right)$ along of the road structure for Case 3 with a $R_{\text {inter } 3}=0.67$. The graph begins with the $K_{0}$ condition (in-situ stress), taking $\mathrm{y}=0.92 \mathrm{~m}$ depth, $N_{3} \mathrm{y}=0.62 \mathrm{~m}, N_{2} \mathrm{y}=0.31 \mathrm{~m}$ and $N_{1} \mathrm{y}=0.0 \mathrm{~m}$ geogrids in its respective depths. In the graph the black continuous line represents the $K_{0}$ condition (in-situ). When the truck load is applied in the road surface (empty squares in the graph), the principal stress $\left(\sigma^{\prime}{ }_{1}=\sigma_{v}\right)$ is increased in all the road structure layers behaving as a triaxial compression test. When there are 3 cavities in the soil (black triangle in the graph), the stresses change their direction in the first two depths ( $\mathrm{y}=0.92 \mathrm{~m}$ and $\left.N_{3}, \mathrm{y}=0.62 \mathrm{~m}\right)$, particularly 
the shear stress decrease with a slight change in the $p^{\prime}$, which means that the $\sigma_{3}^{\prime}=\sigma_{h}$ increase presenting a passive pressure. At $0.31 \mathrm{~m}\left(N_{2}\right)$ and $0.0 \mathrm{~m}\left(N_{1}\right)$ positions, the $\tau_{\text {mob }}$ stresses are increased with the $p^{\prime}$ stresses, reaching their maximum values when three cavities are developed in the ground (compression behavior). In the model with more of 3 cavities the stress changes, reducing having a passive pressure behavior.
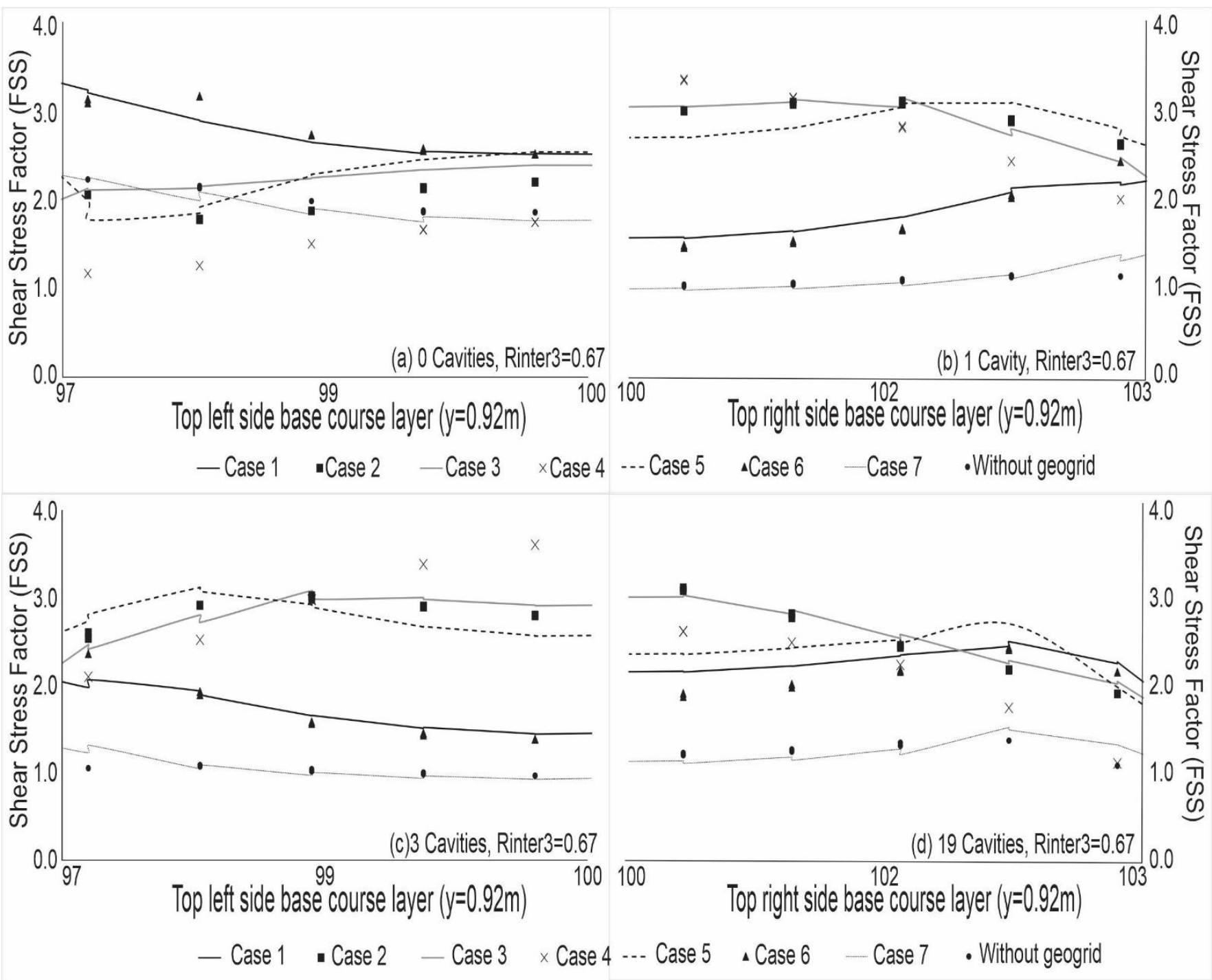

Figure 10. Graph groups of Mobilized FSS along of the base course layer, considering the seven Cases, a $R_{\text {inter } 3}=0.67$, truck load and (a) 0 cavities, (b) 1 cavities, (c) 3 cavities and (d) 19 cavities in the soil.

Furthermore, this Figure illustrates that the stresses are superior in the subgrade of the road structure, verifying that the subgrade layer is the most unfavorable layer in the road structure. The behavior of the stress paths in the Case 3 is the same for all the Cases (Table 2) and for the structure without geogrids, with the difference in the numerical values.

Figure 12 shows the mobilized shear stress $\left(\tau_{m o b}\right)$ evolution in the road structure for the Case $3\left(N_{1}, \mathrm{y}=0.0 \mathrm{~m}\right), N_{2}, \mathrm{y}=0.31 \mathrm{~m}$ and $\left.N_{3}, \mathrm{y}=0.62 \mathrm{~m}\right)$, underlining that the base course layer gets more stressed than the subgrade layer due to the truck load. Nevertheless, the first cavity (Figure 12c) causes a tension between $N_{1}$ and $N_{2}$ levels in the middle of the road structure. This tension is dissipated as there are more cavities in the granular soil (Figure 12d). These kinematics confirm that the subgrade layer is the most stressed place of the road ( $N_{1}$ and $N_{2}$ depths) and that the stresses in the layers vary depending on the number of cavities in the model. 


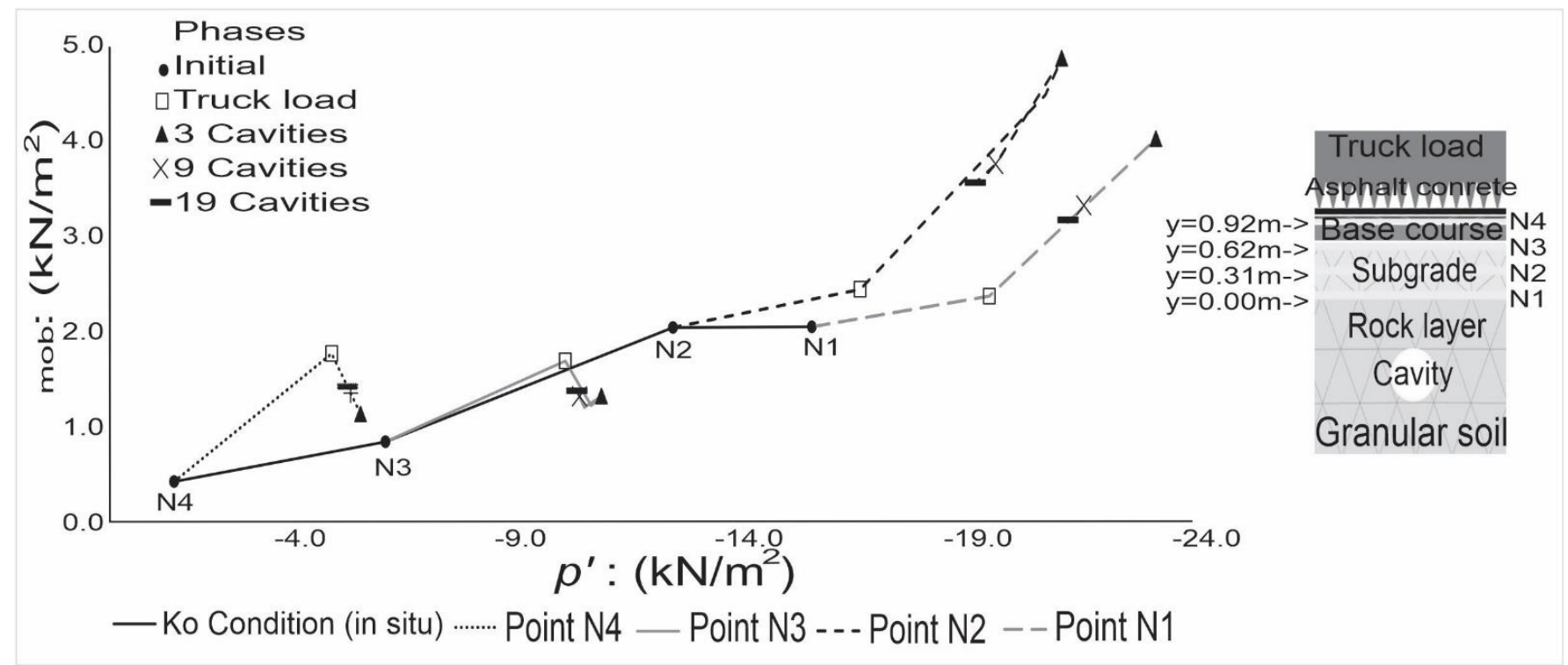

Figure 11. Stress paths in the road structure for four different depths in the middle of the numerical model, Case 3 ( $N_{1}$, $\mathrm{y}=0.0 \mathrm{~m}), N_{2}, \mathrm{y}=0.31 \mathrm{~m}$ and $N_{3}, \mathrm{y}=0.62 \mathrm{~m}$ ), considering the truck load and 3,9 and 19 cavities.

\subsection{Stress Paths $\left(\tau_{m o b}-p^{\prime}\right)$ in the Rock Layer Analyzed with Geogrids in the Road Structure}

The $\tau_{m o b}-p^{\prime}$ stress paths in the rock layer are presented in Figure 13 in three different depths $\mathrm{y}=0.0 \mathrm{~m},-1.9 \mathrm{~m}$ and $-5.0 \mathrm{~m}$ and considering these when there are geogrids (long dashed lines) and without geogrids (grey lines). This last stress paths were collected from the article [3]. It is important to point out, that the magnitude of the static load, is the same in both papers. Nevertheless, in this paper the structure of the road was modelled and the truck load was applied over the asphalt layer and in the first work only one total load (truck load and road structure) was considering directly in the rock surface.

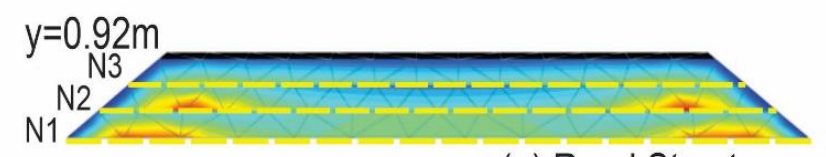

(a) Road Structure

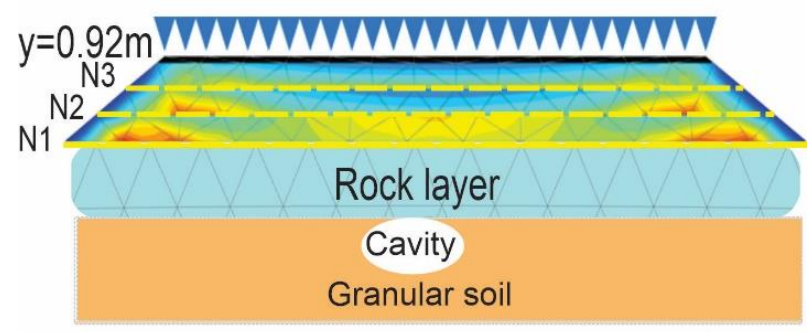

(c) 1 Cavity

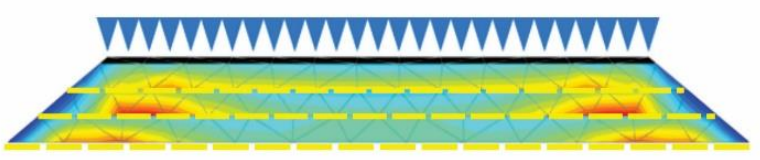

(b) Truck load

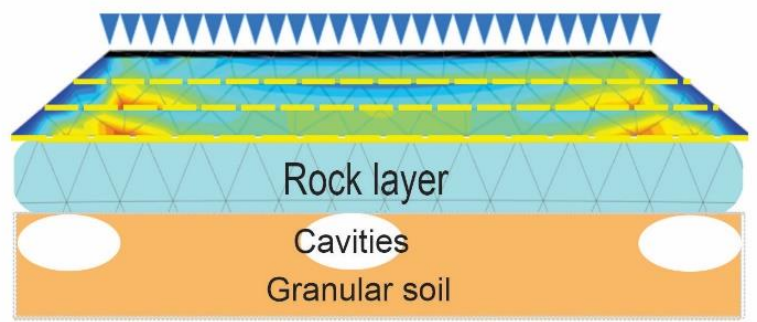

(d) 19 Cavities

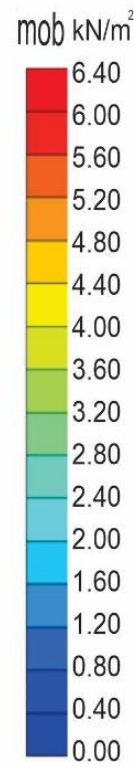

Figure 12. Kinematics for the Case $3\left(N_{1}, \mathrm{y}=0.0 \mathrm{~m}, N_{2}, \mathrm{y}=0.31 \mathrm{~m}\right.$ and $\left.N_{3}, \mathrm{y}=0.62 \mathrm{~m}\right)$, Mobilized shear stress $\left(\tau_{m o b}\right)$ in the road structure, resulted from the FEM analysis with PLAXIS $2 \mathrm{D}^{\circledR}$. (a) Phase without truck load and cavities, (b) Phase with truck load and 0 cavities, (c) Phase with truck load and 1 cavity and (d) Phase with truck load and 19 cavities. 


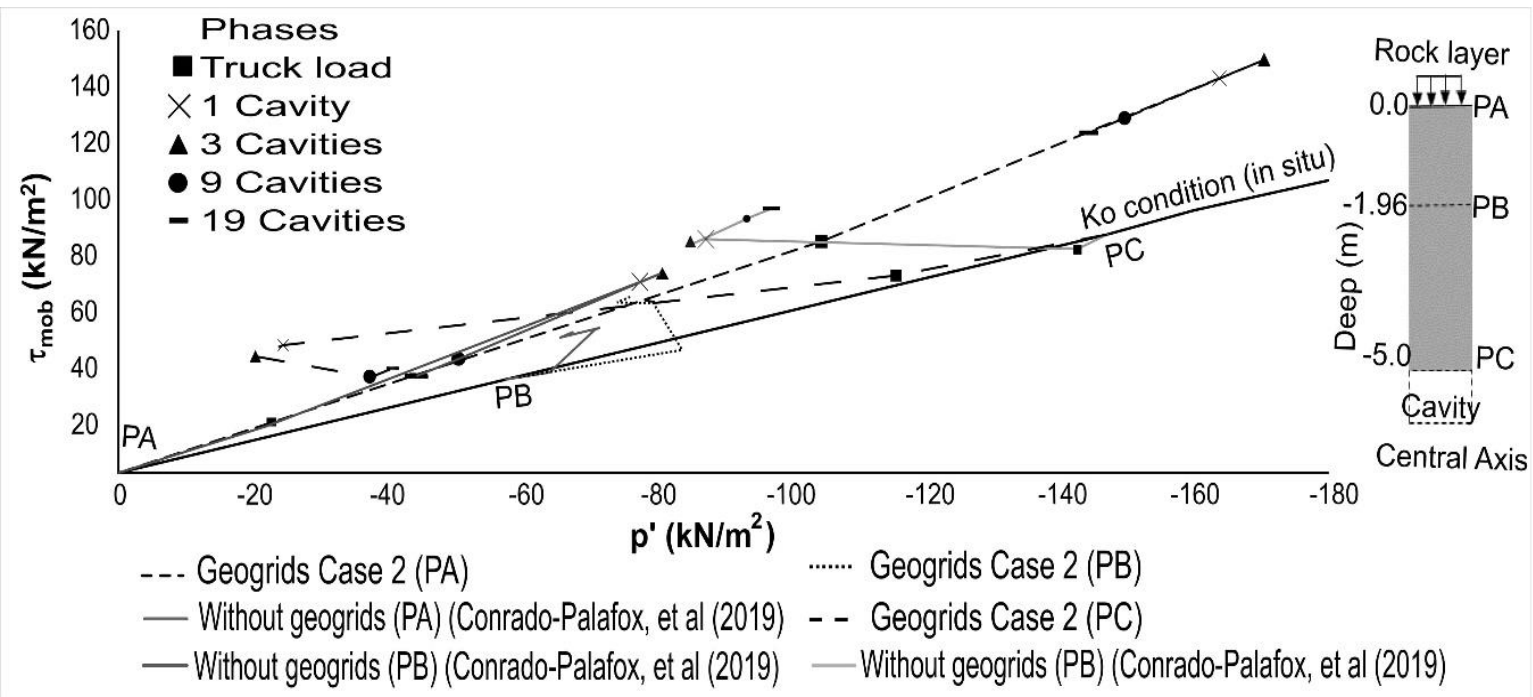

Figure 13. Stress paths in the rock layer for three different depths in the middle of the numerical, Case $2\left(N_{1}, \mathrm{y}=0.0 \mathrm{~m}\right.$ and $N_{2}, y=0.31 \mathrm{~m}$ ) and without geogrids [3], considering the truck load and 3, 9 and 19 cavities.

Furthermore, the results shown with geogrids correspond to Case 2 and with the road structure contemplated in the numerical model. Case 2 was chosen in function of the results presented in the Mobilized FSS in the different road layers for the seven analyzed Cases section, remembering that the best behavior Cases were Case 2 and Case 3 in its performance.

In the surface rock layer (PA, $y=0.0 \mathrm{~m}$ ), the stresses are increased until the 3 cavities (black triangle mark) in both cases (compression behavior). When subsequent cavities are developed, the stresses return following the same line and due to the relaxation effect of the horizontal stress $\left(\sigma_{3}^{\prime}=\sigma_{h}\right)$ with the particularity that in the model with geogrids $\left(N_{1}\right.$ and $N_{2}$ positions-Case 2) it generates stresses with higher values due to the differences in the numerical modeling.

For the two results (with in without geogrids), in the $-1.9 \mathrm{~m}$ depth (PB), the inflexion point is between the 3 cavities and the truck load (square marks), where the $\tau_{m o b}$ increases reaching the maximum value with 19 cavities (black block marks), that means that an effect of the active pressure is presented rock material tends to be get into the holes developed in the ground.

At the base of the rock layer ( $\mathrm{PC}$ ) with geogrids in $N_{1}$ and $N_{2}$ positions, the behavior changes in respect to the previous depths. The $p^{\prime}$ decreases until the phase with 3 cavities in order to change its direction (excavation effect) and the reduction of the $\tau_{m o b}$ when there are more cavities, opposite to the condition when there are not geogrids. This means that the effect of the geogrids benefits the ground behavior when the mobilized shear stress is lesser.

To conclude this section and following the stress paths behavior described in Figure 13, a trend line was proposed and was named as Kcase 2 and is presented in Figure 13. This line was obtained by joining the $\tau_{m o b}-p^{\prime}$ points in the phase with 9 cavities at the different depths of the rock layer and when the road structure has 2 geogrids in $N_{1} \mathrm{y}=0.0 \mathrm{~m}$ and $N_{2}$ $\mathrm{y}=0.31 \mathrm{~m}$ depths (Case 2).

This trend was compared with the Kwithout geogrids line proposed by ConradoPalafox [3], where its results indicated that the stratigraphy without cavities supports the highway load; nevertheless, with 9 cavities in the granular soil the stress path changes direction, affecting the terrain surface and presenting a subsidence.

Kcase 2 trend indicates that with geogrids in the road structure, the $\tau$ mob are lesser in the rock layer, resulting in a minor slope. This tendency corroborates the satisfactory influence of the inclusion of the geogrids in the amelioration of the road structure when exist cavities in the ground. (Figure 14). 


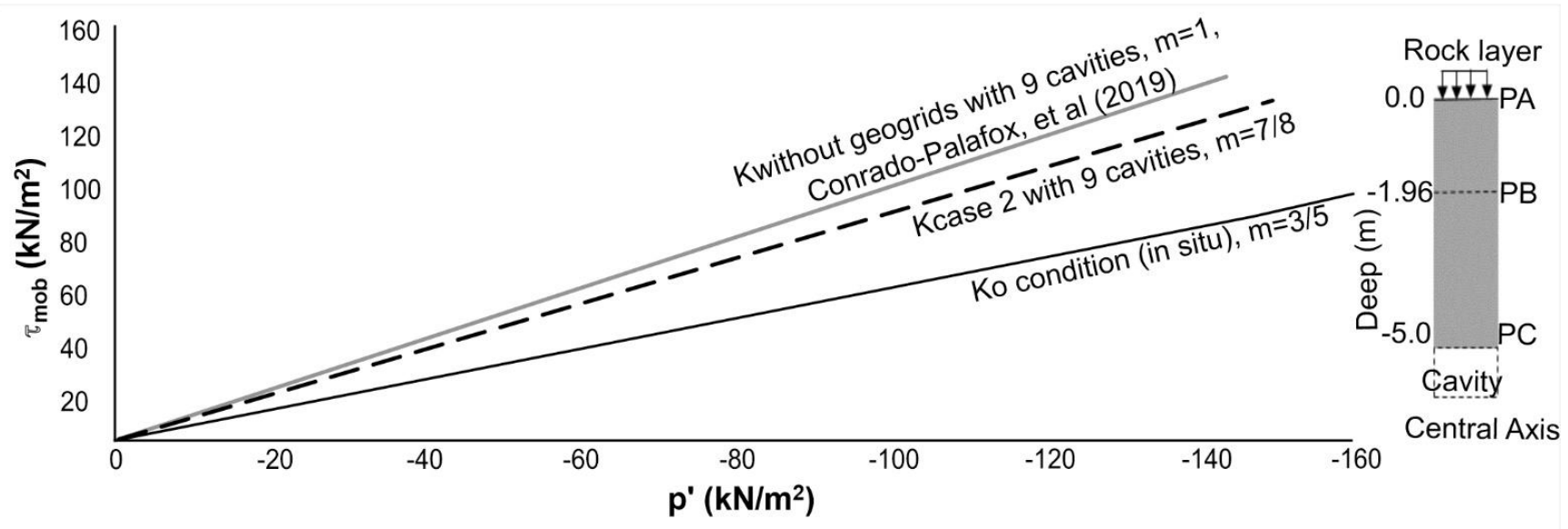

Figure 14. Variation in the in-situ stresses $\left(K_{0}\right)$ in the rock layer, for the Case 2 (geogrids in $N_{1}$ and $N_{2}$ depths) and without geogrids [3] in the phase with 9 cavities in the ground.

\section{Discussion}

The present study was designed to determine the effect of the geogrid layers in a road, affected by the subsidence created by the cavities in the subsoil. Results are shown in terms of the stress paths, due to the stresses permit to visualize, which of the three layers of the road (subgrades and basecourse), was less compromised in the moment of the subsidence developed in the terrain. Combination of the geogrid positions were simulated to find the best combination.

The findings obtained based on these finite element modeling, confirm the increase of stresses and the low values of stress shear factor when there are many cavities in the model, but also confirm the stabilization of the terrain after several open cavities, because the stress shear factor in the road layers increase. This performance is attributed to the position of the cavities, those closest to the road affect more.

As it was expected, the combination Case 4 of geogrids is the best combination to improve the structure. However, this reinforcement is unacceptable in the construction community due to the cost to build roads with geogrids. Furthermore, this study points out the unnecessary to reinforce the base course layer, because the damage is absorbed mainly in the subgrade layers. This conclusion must be analyzed under cyclic loads on the crest of the road, which certainly would affect the base course performance.

This study set out the necessity, to reinforce the subgrade layer and most importantly only reinforce the middle and the top of the subgrade layer to reduce the stress shear factor in the road structure due to the cavities. Furthermore, the decrease in the slope of the stress paths ( $\tau_{m o b}$ vs. $p^{\prime}$ ) in the rock layer with the presence of the geogrids in the road was founded in this study, which guarantees a better behavior.

In general, previous studies have pointed out the geogrids as an adequate reinforcement method, for several structure problems such as poor bearing capacity in the road layers, clay problems in the subsoil and problems due to one cavity under the road. With this study it is possible to verify the geogrids, as a solution in terrains affected by karsticity, specially with several cavities in one area.

Further studies, which take these results into account, will need to be undertaken to increase the improvement of the geogrids in the road construction. As well as future investigations based in real road construction in similar karst terrain are recommendable to join the analytic results with construction performance and in the future modify the Mexican road construction in karst terrain standards and considering the effect of cyclic loads. 


\section{Conclusions and Future Research}

The infrastructure construction is necessary in the world and this will continue even in karstic terrains. The high frequency of mechanical failure in karst terrains is a handicap due to the dissolution of the young limestone. Therefore, substantial improvements in the prevalent construction practices are needed, due to the demographic and economic evolution.

In this work numerical FEM models are presented for a typical road structure, to verify the effect of the reinforcement provided using geogrids, when cavities in the ground are presented and developed over time. To select the optimal numerical model, the granular soil and the bedrock was modeled using parameters found in the endemic geomaterial in Merida, Mexico. The dimensions and the thickness layers of the subgrade, the base course, and the asphalt concrete, correspond to those used in the typical constructions found in the zone as well as its materials characteristics. Geogrid characteristics simulated are for an elastic material and the values of its resistance were obtained of the literature references regarding this topic.

Several interfaces $R_{\text {inter }}$ values were studied to study the influence of the adherence among the road layer and the geogrids. Results illustrate that a decrease of the FSS value is obtained in the road layers with the decrease of the interface value.

In this work, the nine cavities in the granular soil of the stress path have unfavorable behavior, because they presented a change in the stress path direction, affecting the terrain surface and presenting a subsidence, despite cavities existing away from the road structure. These results are corroborated with the FSS that stop to decrease and since shear stress is dissipated. According to the stress paths presented and the kinematics, the subgrade is the most stressed layer in the structure when the cavities are presented in the numerical model.

The FSS of the road with 2 or 3 geogrid layers (Case 2 and Case 3) showed the best improvement when cavities are present in the subsoil, concluding that the geogrid enhances the stress distribution and generates less $\tau_{m o b}$ in all structural road layers, nevertheless the subsidence will continue to be present on the surface of the rock layer but with a minor displacement.

From the numerically generated stress paths when geogrids are added, a trend line was proposed following the $\tau_{\text {mob }}$ presented in the ground. This line unites the most unfavorable phase that is presented with 9 cavities in rock layer and when the road structure has 2 geogrids in the road structure. This trend was compared with the line that did not use geogrids proposed by Conrado-Palafox [3], which represents the buffering of the stresses when geogrids are used.

Finally, it should be noted, that additional studies are needed in order to improve the computational karstic model for example incorporating the cavities in a random location in the subsoil and to evaluate the geogrid in the base course layer position under cyclic load considering the karsticity. This study represents a benefit for the regions with karstic soils by proposing a change in the construction practices.

Author Contributions: Investigation, A.L.C.-P. and V.A.H.-H.; Supervision, L.N.E.-A. All authors have read and agreed to the published version of the manuscript.

Funding: This research received no external funding.

Data Availability Statement: No applicable.

Conflicts of Interest: The authors declare no conflict of interest.

\section{References}

1. Van Beynen, P.E. (Ed.) Introduction. In Karst Management: 1-5, 1st ed.; Springer: Dordrecht, The Netherlands, 2011.

2. Lukic-Tanovic, M.; Golijanin, J.; Susnjar, S. Impact of population on the karst of east Sarajevo (Bosnia and Herzegovina). J. Geogr. Inst. Civijic 2019, 69, 95-107. [CrossRef]

3. Conrado-Palafox, A.; Equihua-Anguiano, L.; Orozco-Calderón, M.; Arreygue-Rocha, E. Numerical simulation of karst environments to study subsidence. Proc. Inst. Civ. Eng. Geotech. Eng. 2019, 172, 365-376. [CrossRef]

4. Gaona-Vizcayno, S.; Gordillo-de Anda, T.; Villasuso-Pino, M. Cenotes, Karst característico: Mecanismos de formación. Rev. Mex. de Cienc. Geol. 1980, 4, 32-36. 
5. Connors, M.; Hildebrand, A.R.; Pilkington, M.; Ortiz-Aleman, C.; Chávez, R.E.; Urrutia-Fucugauchi, J.; Graniel-Castro, E.; Camara-Zi, A.; Vasquez, J.; Halpenny, J.F. Yucatán karst features and the size of Chicxulub crater. Geophys. J. Int. 1996, 127, F11-F14. [CrossRef]

6. Springall, G.; Espinosa, S.L. El subsuelo de la Península de Yucatán. Reunión de Mecánica de suelos 1972, 4, Y-1-Y-102.

7. Bauer-Gottwein, P.; Gondwe, B.R.N.; Charvet, G.; Marín, L.E.; Rebolledo-Vieyra, M.; Merediz-Alonso, G. Review: The Yucatán Peninsula Karst Aquifer, Mexico. Hydrogeol. J. 2011, 19, 507-524. [CrossRef]

8. Escolero, O.A.; Marin, L.E.; Steinich, B.; Pacheco, A.J.; Cabrera, S.A.; Alcocer, J. Development of a protection strategy of karst limestone aquifers: The Merida Yucatan, Mexico case study. Water Resour. Manag. 2002, 16, 351-367. [CrossRef]

9. Moreno-Gómez, M.; Liedl, R.; Stefan, C. A New GIS-Based Model for Karst Dolines Mapping Using LiDAR: Application of a Multidepth Threshold Approach in the Yucatan Karst, Mexico. Remote Sens. 2019, 11, 1147. [CrossRef]

10. Paredes, C.; Matos, H.; De la Vega, R.; Pardo, E. Reconocimiento semiautomático de depresiones kársticas mediante análisis clúster de las distribuciones morfométricas y su aplicación al karst del Estado de Yucatán, México. Rev. Mex. Cienc. Geol. 2019, 36, 270-288. [CrossRef]

11. Fiore, A.; Fazio, N.L.; Lollino, P.; Luisi, M.; Miccoli, M.N.; Pagliarulo, R.; Perrotti, M.; Pisano, L.; Spalluto, L.; Vennari, C.; et al. Evaluating the susceptibility to anthropogenic sinkholes in Apulian calcarenites, southern Italy. Geol. Soc. London Spec. Publ. 2018, 466. [CrossRef]

12. Cooper, A.; Farrant, A.; Price, S. The use of karst geomorphology for planning, hazard avoidance and development in Great Britain. Geomorphology 2011, 134, 118-131. [CrossRef]

13. Bonacci, O. Hazards caused by natural anthropogenic changes of catchment area in karst. Nat. Hazards Earth Syst. Sci. 2004, 4, 655-661. Available online: https:/ / hal:00299207 (accessed on 25 August 2021). [CrossRef]

14. Rodríguez-Huerta, E.; Rosas-Casals, M.; Hernández, L.M. Water societal metabolism in the Yucatan Peninsula. The impact of climate change on the recharge of groundwater by 2030. J. Clean. Prod. 2019, 235, 272-287. [CrossRef]

15. Waltham, T.; Bell, F.; Culshaw, M. Sinkholes and subsidence. In Karst and Cavernous Rocks in Engineering and Construction; Springer: Berlin/Heidelberg, Germany, 2005.

16. Andriani, G.F.; Walsh, N. An example of the effects of anthropogenic changes on natural environment in the Apulian karst (southern Italy). Environ. Geol. 2009, 58, 313-325. [CrossRef]

17. Mariola, K.; Malgorzata, S.; Aneta, S.; Iga, L. The impact of environmental factors on benthos communities and freshwater gastropod diversity in urban sinkhole ponds in roadside and forest contexts. Landsc. Res. 2019, 44, 477-492. [CrossRef]

18. Smart, P.L.; Beddows, P.A.; Coke, J.C.; Doerr, S.; Smith, S.; Whitaker, F.F. Cave development on the Caribbean coast of the Yucatan Peninsula, Quintana Roo, Mexico. Geol. Soc. Am. Spec. Pap. 2006, 404, 105-128. [CrossRef]

19. Zeng, Y.; Zhou, W. Sinkhole remedial alternative analysis on karst lands. Carbonates Evaporites 2019, 34, 159-173. [CrossRef]

20. Pueyo-Anchuela, O.; Soriano, M. Integrated geophysical and building damages study of karst effects in the urban area of Alcalá de Ebro, Spain. Zeitschrift für Geomorphol. 2010, 54, 221-236. [CrossRef]

21. Gutiérrez, F.; Benito-Calvo, A.; Carbonel, D.; Desir, G.; Sevil, G.; Guerrero, J.; Martínez-Fernández, A.; Karamplaglidis, T.; García-Arnay, A.; Fabregat, I. Review on sinkhole monitoring and performance of remediation measures by high-precision levelling and terrestrial laser scanner in the salt karst of the Ebro Valley, Spain. Eng. Geol. 2019, 248, 283-308. [CrossRef]

22. Saenseela, S.; Poungchompu, P.; Chairatanangamdej, G. Settlement behavior of road surfaces caused by dissolution of salt layers. Int. J. GEOMATE 2019, 17, 57-61. [CrossRef]

23. SCT (Secretaría de Comunicaciones y Transportes). (n.d.). Catálogo de secciones estructurales de pavimentos para las carreteras de la república mexicana. Dirección General de Servicios Técnicos, México. Available online: http:/ /www.sct.gob.mx/fileadmin/ DireccionesGrales/DGST/Manuales/Catalogo_Pavimentos/Catalogo.pdf (accessed on 25 August 2021). (In Spanish).

24. Adlinge, S.S.; Gupta, A.K. Pavement deterioration and its causes. Int. J. Innov. Res. Dev. 2013, 2, 437-450.

25. Benmebarek, S.; Berrabah, F.; Benmeberak, N.; Belounar, L. Effect of Geosynthetic on the performance of road embankment over Sabka soils in Algeria: Case Study. Int. J. Geosynth. Ground Eng. 2015, 4, 35. [CrossRef]

26. Majedi, P.; Ghalehjough, B.K.; Akbulut, S.; Celik, S. Effect of Reinforcement on stability and Settlement of Embankment: A finite element analysis of different kinds of reinforcing and construction conditions. Eur. J. Adv. Eng. Technol. 2017, 4, 759-764.

27. Singh, M.; Trivedi, A.; Shukla, S.K. Strength enhancement of the subgrade soil of unpaved road with geosynthetic reinforcement layers. Transp. Geotech. 2019, 19, 54-60. [CrossRef]

28. Gu, F.; Lou, X.; Luo, R.; Hajj, E.Y.; Lytton, R.L. A mechanistic-empirical approach to quantify the influence of geogrid on the performance of flexible pavement structures. Transp. Geotech. 2017, 13, 69-80. [CrossRef]

29. Wang, Z.; Jacobs, F.; Ziegler, M.; Yang, G. Visualisation and quantification of geogrid reinforcing effects under strip footing loads using discrete element method. Geotext. Geomembr. 2020, 48, 62-70. [CrossRef]

30. Jiang, Y.; Nimbalkar, S. Finite Element Modeling of Ballasted Rail Track Capturing Effects of Geosynthetic inclusions. Front. Built Environ. 2019, 5, 69. [CrossRef]

31. Ngo, N.T.; Indraratna, B.; Rujikiatkamjorn, C. Modelling geogrid-reinforced railway ballast using the discrete element method. Transp. Geotech. 2016, 8, 86-102. [CrossRef]

32. Wang, F.; Han, J.; Miao, L.C.; Bhandari, A. Numerical analysis of geosynthetic-bridged and drilled shafts-supported embankments over large sinkholes. Geosynth. Int. 2019, 16, 408-419. [CrossRef] 
33. Sireesh, S.; Sitharam, T.G.; Sujit Kumar Dash. Bearing capacity of circular footing on geocell-sand mattress overlying clay bed with void. Geotext. Geomembr. 2009, 27, 89-98. [CrossRef]

34. Galve, J.; Gutiérrez, F.; Guerrero, J.; Alonso, J.; Diego, I. Optimizing the application of geosynthetics to roads in sinkhole-prone areas on the basis of hazard models and cost-benefit analyses. Geotext. Geomembr. 2012, 34, 80-92. [CrossRef]

35. Plaxis. Plaxis 2D: Reference Manual; Plaxis: Delft, The Netherlands, 2017.

36. Finch, W.A. The Karst Landscape of Yucatan; National Research Council: Washington, DC, USA, 1965.

37. SCT (Secretaría de Comunicaciones y Transportes). Norma NOM-012-SCT-2-2017. Diario Oficial de la Federación de México, México City, México. 26 December 2017. Available online: https: / /www.dof.gob.mx/nota_detalle.php?codigo=5508944\&fecha= 26/12/2017 (accessed on 25 August 2021). (In Spanish).

38. Augarde, C. Prediction of undrained sinkhole collapse. J. Geotech. Geoenviron. Eng. 2003, 129, 197-205. [CrossRef]

39. Oh, J.H. Investigation of Geogrid-Reinforced Flexible Pavement Performance Over Expansive Clay. J. Korean Soc. Hazard. Mitig. 2011, 11, 109-116. [CrossRef]

40. Estrada-Media, H.; Wes, T. Identification of underground karst features using Ground Penetration Radar in Northern Yucatán, México. Vadose Zone J. 2010, 9, 653-661. [CrossRef]

41. Rocscience Inc. RocData 5.0: Modeler, Version 9.020 64-bit, Copyright (c) 1990-2016; Rocscience Inc.: Toronto, ON, Canada, 2017.

42. Parry, R.H. Mohr Circles, Stress Paths and Geomechanics, 2nd ed.; Taylor \& Francis Group: London, UK, 2004. 